\title{
"BEYOND RELIGIONS AND EVEN BEYOND MANKIND": KARL SHAPIRO'S JEWISH WALT WHITMAN
}

\author{
DARA BARNAT
}

The Jewish-American PoET most widely associated with Walt Whitman is Allen Ginsberg. Ginsberg famously adopted Whitman into his Beat-generation poetry, with its countercultural agenda, flaunting of the body and sexuality, and style replete with long, enumerative lines. ${ }^{1}$ Yet, extensive critical attention to Ginsberg has fostered the misconception that he is the primary, or sole, Jewish-American poet with a significant relationship to Whitman. In fact, numerous Jewish-American poets have upheld such relationships, although most remain underexamined. ${ }^{2}$ Failing to interrogate these connections not only limits our understanding of Whitman's role in American literature and culture;it also limits our understanding of a mode by which Jews have shaped and defined their poetry and identity in America.

Karl Shapiro, author of the seminal, Jewish-themed collection of poetry, Poems of a few (1958), is a poet whose relationship to Whitman has been regrettably dwarfed by Ginsberg's. ${ }^{3}$ Shapiro, too, was an adamant champion of Whitman; yet, the poetic, political, and social implications of this championing have been thus far overlooked. With the exception of a very few critical investigations, in fact, many aspects of Shapiro's work have suffered neglect in recent decades. ${ }^{4}$ The decline in Shapiro's career and reputation from its height in the 1940s, 1950s, and 1960s has been attributed to the vicious public attacks he leveled upon leading Modernist figures of the time, primarily Ezra Pound and T. S. Eliot, as well as W. B. Yeats. Crucially, Shapiro's opposition to these figures, whom he perceived to be exclusionary, right wing, and anti-Semitic, was profoundly motivated by his identity as a Jew in general, and a Jewish poet in particular.

Whitman was not merely a marginal player in Shapiro's confrontation with these Modernist poets, whose opinions of Whitman were at best ambivalent, at worst hostile. Rather, Whitman was at center stage. ${ }^{5}$ Never one to modulate his viewpoints, Shapiro openly lauded Whitman in essays, poetry, and interviews: "Walt Whitman has had more influence on my poetic thinking than anybody." Shapiro valued Whitman 
above other writers he respected, such as William Carlos Williams, Emily Dickinson, W. H. Auden, D. H. Lawrence, Henry Miller, Randall Jarrell, and Hart Crane. ${ }^{7}$ This essay will demonstrate how Shapiro fashioned Whitman into an ally against the more conservative elements of the Modernist poetic milieu. ${ }^{8}$ Shapiro, experiencing himself marginalized from the mainstream as a Jew and poet, views Whitman in a similarly marginalized position in American society. Indeed, Shapiro's portrayals of Jews and Jewishness in his writing can be seen to parallel his portrayals of Whitman, thus demonstrating how Shapiro comes to imagine Whitman implicitly as a Jew.

This study of Shapiro and Whitman seeks to provide a more nuanced understanding of how Whitman features in American literature more broadly, and the Jewish-American poetic tradition more specifically. We will see how, as Shapiro interprets Whitman, Whitman himself is inevitably transformed, politicized, and "ethnicized."

\section{Karl Shapiro's Outsider Identity}

To grasp why Shapiro found such significance in Whitman, it is crucial to pause on Shapiro's sense of identity, which, as an American, a Jew, and a poet, was vexed. Ironically, in terms of national identity, many scholars considered Shapiro to be quintessentially American, noting his use of idiomatic language and depictions of middle-class life. ${ }^{9}$ Hayden Carruth stated, "Shapiro was derivative but never imitative. He was an American."10 Shapiro's Pulitzer Prize-winning collection V-Letter and Other Poems (1945), written during his World War II military service, further solidified his reputation as an American poet. Hilene Flanzbaum writes that the various personas assumed by Shapiro in his war poetry made him broadly appealing: "Shapiro has written poems about being Jewish and Christian, Native-American and Black, wounded and healthy, and it is indeed part of his point that as the composite American - and most important, as the ideal American soldier-he can be any of these things" (263). Shapiro was thus perceived to be an American poet, though not necessarily a Jewish one.

To some degree, Shapiro cultivated this role of national American poet. ${ }^{11}$ In the essay "Notes on Raising a Poet," his notion of an ideal American poetry seems to reflect not only his own poetic style, but a collective to which he belonged: America, "us."

What would American poetry be like, to deserve a name? Answer: It would be nonsensical, hilarious and obscene like us. Absurd like us. ... It would be mystical, savage and drab. ... (130) 
Fundamentally, however, Shapiro was never at peace with the designation of American poet and tended to minimize, or outright deny, this role:

Words like "spokesman" and "touchstone" took me completely by surprise. . . Not only had I been out of the country when my first two books were published, but I have always been "out of the country" in the sense that I never had what ordinarily is thought of as a literary life, or been part of a literary group.... I never had any of that and still don't. ... (Phillips 50)

Shapiro's resistance to serving as a representative or "spokesman" bespeaks an exilic state: American, yet "out of the country" in a symbolic way. Though Shapiro held positions that placed him in the high echelons of American poetry, as a professor at several major universities, the chief editor of Poetry Magazine, ${ }^{12}$ and a poetry consultant at the Library of Congress in 1946, his outsiderness extended as well to realms such as these: "I have a sort of special status around English departments. I'm not really a professor, but sort of a mad guest" (Phillips 62).

Perhaps the main reason for Shapiro's sense of outsiderness in America was his identity as a Jew, an outsiderness compounded by his troubled attitude towards Jewishness itself. Born in 1913, Shapiro claims to have been raised "Jewish, Depression, intellectual, poetic. . . . I was a Baltimorean, a 'Southerner."'13 Unlike his family, Shapiro was not religiously observant. When Robert Phillips asks Shapiro "What has being Jewish done to your work?" the latter describes resisting Judaism, even flirting with Catholicism:

Just everything. I went through a period, like many middle-class Jews, in which I consciously drew away from religion and everything Jewish in my life. And I think for a long time, say in the 1930 s, I felt completely cured of the religious virus. . . . During the war, I became more interested in Christianity. ... I had a friend who used to write me enormously long letters. She was a very religious Catholic who wanted to become a nun. And she tried to convert me. . . I think I was hypnotized-she almost succeeded. (Phillips 60-61)

Shapiro's cynicism regarding the "virus" of religion was not exclusive to him, but in fact typified the attitude of many secular, left-wing Jewish American writers and artists of the period..$^{14}$ In keeping with this attitude, Jewishness was a crucial aspect of Shapiro's self-identification, which pervaded his writing, but was a cultural identity, rather than a strictly religious one.

The outsider condition of being a Jew for Shapiro was intertwined with the condition of being a poet, both core identities and sources of tension for him. "I have always had this feeling-I've heard other Jews 
say - that when you can't find any other explanation for Jews, you say, 'Well, they are poets.' There are a great many similarities. This is a theme running through all my stuff from the very beginning. The poet is in exile whether he is or he is not" (Phillips 60). Statements such as this one likely allude to Marina Tsvetayeva's oft-quoted assertion that "All poets are Jews." Shapiro's expression of "exile" evokes John Hollander's notions in "The Question of American Jewish Poetry"; first, that Jews are "outsiders, by nature itinerant no matter how locally rooted," and second, that Jews exist in "a kind of linguistic galut." 15 This theme of galut (the Hebrew term for exile or Diaspora) appears throughout Shapiro's work. In "Poet," he writes that the Jew and the poet "shall be always strange" (CP 41-42). In another poem, "Travelogue for Exiles," the theme of outsiderness is evident not only in the title ("exile"), but in the repeated line: "this is not your home" (Poems of a few 18). This line can perhaps be understood as a remark about the human condition of outsiderness; however, in context with the Jewish themes of Shapiro's work, it must also be understood to reference a particularly Jewish sense of exile. ${ }^{16}$

Shapiro's experience of marginalization in the national, ethnic, religious, and professional realms is the basis for his affiliation with Whitman, whereby he perceives Whitman to be in a similar, exiled position in America. As a Jew, Shapiro's marginalization was not merely self-imposed. Somewhat in parallel, Whitman had sought to situate himself as America's poetic spokesperson, "commensurate with a people,"17 but, as we will see, was rejected or exiled by certain leading Modernist poets, the very ones who contributed to Shapiro's own exile. Shapiro therefore perceives Whitman to be a poet in exile, the same role Shapiro designated for himself, and which was imposed upon him.

\section{Shapiro, Modernism, and Whitman}

Shapiro claimed in numerous sources that he viewed Whitman's inclusive, spontaneous, liberal ethos to be a corrective to the elitist, antiSemitic attitudes he associated with Pound, Eliot, and Yeats. "What," asks Shapiro, "has happened to Whitman in the century since Leaves of Grass was published?"18 This ostensibly simple question, posed in "The First White Aboriginal," contains a deep-seated criticism of the attitudes of these Modernist figures. A similar critique appears in this essay, where Shapiro claims: "The power of Walt Whitman in the world is incalculable" (173). Several years later, in "Is Poetry an American Art?," he would write: "We [America] have given birth to only one poet before the present century - Walt Whitman. There are a few false starts, such as Poe and Emily Dickinson. The rest is padding." ${ }^{19}$ Shap- 
iro's dislike of the aesthetics and politics of the right-wing Modernists is embodied in yet another claim of the same essay, "Once upon a time there was a thing called poetry; and . . it was very beautiful and ... people tried to bring it to our shores in boats, but it died" (45). The rhetoric of Shapiro's statements is in keeping with what Robert W. Daniel refers to as "[The] belligerent, iconoclastic, exasperating/stimulating style [that] seems to keep [Shapiro] ever in an adversary relationship with something or somebody." 20

However, Shapiro's impudent tone should not be taken as a diminishing of the seriousness and gravity of his resistance to the Modernist poets. In The Poetry Wreck, Shapiro condemns "the political simplemindedness and viciousness of the great trio of Pound, Eliot and Yeats," giving voice to his acute disapproval of their aesthetics and ideologies ${ }^{21}$ :

Never mind their fascism, with or without the large F. . . The real triumph of these famous old poets was of course never in the world of politics but in the Academy. They defined an attitude toward literature and gave it an intellectual sanction. Sophisticated schools of criticism sprang up to defend their aesthetic - the aesthetic of anti-humanism. ... The abreaction to that eventuated in a poetry that was nothing but political, a poetry of the subjective revolution, of ego, of self-pity and of self-regard. (16)

Shapiro takes care to hone in on each member of the "trio" individually. Regarding Pound, he maintains, "Any way you look at it, writing about Ezra Pound and his poetry is unpleasant business. . . . Pound is not the kind of writer who once did something wrong and can now be forgiven in the mellowness of time. ... He is righteous about his wrongness; he forces his worst upon us whenever we meet him, and there is no escaping it" (29). In "The Death of Literary Judgment" (from The Poetry Wreck), Shapiro similarly denounces Eliot: “[Eliot] resembles one of those mighty castles in Bavaria which are remarkably visible, famed for their unsightliness, and too expensive to tear down" (3-4).

In 1948-1949, the rift between Shapiro and these Modernist poets was deepened when Williams' Paterson and Pound's Pisan Cantos were both nominated for the 1948 Bollingen Prize. The prize committee, comprised of major literary figures, including (in addition to Shapiro), Eliot, Auden, and Lowell, voted to give the award to Pound. The next day Shapiro changed his vote, stating he could not "endorse an antiSemite" for the prize (Rubin 111). Shapiro reports that the circumstances around the Bollingen Prize were a "turning point" in his life, as well as "a great blow to me, the publicity and the scandal. I was suddenly forced into a conscious decision to stand up and be counted as a Jew." Shapiro states that if not for "the anti-Semitic and anti-American propaganda" in Pisan Cantos, he would have voted for Pound, despite the fact that he supported Williams (Phillips 61). 
Shapiro's denunciation of Pound and Eliot grew from his belief that they propagated an exclusionary framework, one that not only kept him (as a Jew) an outsider, but also imprisoned poetry in the academy, thus withdrawing it from the popular realm. As Flanzbaum notes, by resisting the New Critical hold on the Academy Shapiro resisted the "inaccessibility" of poetry: "For Shapiro, poetry heals and unites, it has a social function, it makes community, and is central to the well-being of America" (263). Shapiro argued that Eliot especially led American poetry away from the people, at a time when poetry "had got into the street, into the open air. People, even newspapers understood that America was beginning to write its own poetry." Shapiro went so far as to equate "Newcrit" with Orwell's "Newspeak," lamenting Modernist poetry as "crumbling towers occupied by anachronistic eccentrics and a numberless mob of imposters and mountebanks" ("The Three Hockey Games" 285; "Is Poetry . . ." xvii). Shapiro viewed the New Critical movement as intolerant to ethnic writers and writers of color: "The highbrow magazines, always on the side of power-culture, refuse to recognize the existence of a revolt. ... The Academy observes a kind of token assimilation of the Beat, just as the big Southern universities admit three Negroes a year. A few professors like myself are permitted to hang on, but nobody knows when the knock is coming at the door" ("The Three Hockey Games" 285).

Of course, it wasn't just Shapiro whom the knock was meant for, but Whitman, too. According to Shapiro, Whitman was "sent packing" as soon as Eliot began to "manipulate" poetry ("The Three Hockey Games" 285). Shapiro found the Modernists' negativity toward Whitman all the more significant because they minimized Whitman's influence on their work: "And what are we to make of the paradox, for example, of Pound's dependence on Whitman's prosody while rejecting the sense of Whitman's poetry. And Hart Crane's identification with the sense of Whitman, while rejecting the revolutionary forms?" ("Is Poetry ..." 397). In "Notes on Raising a Poet," Shapiro underscores this hypocrisy in the Modernist rejection of Whitman: "all other American poetry tries, though most would deny it, to measure up to Leaves of Grass. It can be argued that The Waste Land and even the Cantos are redactions of Leaves of Grass" ("Is Poetry ..." 130). Elsewhere, Shapiro suggests the reason for this hypocrisy: that Whitman's pluralistic vision threatened the underpinnings of the Modernists' beliefs:

Whitman had the greatest insight after all. This might account for his unpopularity in America. For Whitman is unpopular not only with Americans at large-nonexistent would be a better word-he is also unpopular with poets. Whitman is dangerous to American poets, like a pesticide. ("Is Poetry . . ." 397) 
Given Shapiro's antipathy to discriminatory attitudes of New Criticism, it is unsurprising that Shapiro's spokesman for America-Whitmanwould possess a contrasting spirit of egalitarianism and democracy. Indeed, in "The First White Aboriginal," Shapiro seeks to "reevaluate" "misunderstandings" about Whitman - in other words, revitalize his reputation - which had been damaged by the Modernist milieu ("Is Poetry ..." 5). In this essay, Shapiro extols D. H. Lawrence for valuing Whitman and "acknowledging him with love" (157). However, Shapiro also states that Lawrence was "inferior" to Whitman and that Whitman was the single democratic poet of America: "At a single stroke, apparently without preparation, Whitman became the one poet of America and Democracy" (159). For Shapiro, Whitman is the paradigm of the American nation: "When I read Whitman, good or bad, I always feel that here is first and foremost an American" (166).

Shapiro not only positions Whitman as a poet of democracy, but an inventor of a uniquely American prosody, thus highlighting poetic style in addition to cultural or national distinctions. This positioning is revealed, for instance, in a passage from Essay on Rime:

Whitman's metric is maladroit, at times

As flaccid as the gentle curve of Longfellow's

Evangeline, but at its best the strongest

Link in American prosody. In fact,

If any one poet fathered a new form

And freed us from the traditional. . . ${ }^{22}$

Although possible hints of discomfort with Whitman's sexuality may be heard in terms like "flaccid" and "gentle," and his sense of meter is explicitly criticized, Shapiro nonetheless describes Whitman's poetic style as the "father," the "strongest link," the hero who liberates America from the "traditional."

At the same time that Shapiro considered Whitman to be quintessentially American, he also believed Whitman to be a mystic, whose vision transcended cultural, national, and religious identifications. Shapiro made frequent references to Whitman's mystical nature, for instance in response to Phillips' query, "In the middle or late fifties, Whitman became very important to you - almost in religious terms. Can you comment on that? And what about Poe?"

Poe was the father of symbolism, so Poe never appealed to me. . . On the other hand, there was Whitman. Whitman to me is the most fascinating of American poets. Whitman started to write the great poetry from scratch after he had written all that junk for newspapers, the sentimental lyrical poetry. All of a sudden, he wrote Leaves of Grass. . . . I was completely bowled over by this, not having been able to explain 
how Whitman came to write "Song of Myself," which is unlike anything not only in American literature, but unique in all the world. The parallels to it are mystical literature. (Phillips 55-56)

In "Cosmic Consciousness" Shapiro yet again alludes to this idea of Whitman as mystic, claiming that Leaves is a "mystical document," which "plunges into the central mystical experience of Whitman's poetry." ${ }^{23}$ Earlier in the same essay, Whitman is said to possess "cosmic consciousness." ${ }^{24}$ Shapiro claims that Whitman's cosmic consciousness marked him as "a member of a new species of the [human] race. He is characterized by a state of moral exaltation, enhanced intellectual power, a feeling of elevation" (31). Elsewhere, the mystic turns prophet: "[Whitman] sprouted ... vegetated . . . loafed out of nowhere into the role of prophet and seer ... he is the one mystical writer of any consequence America has produced" ("White Aboriginal" 157). Shapiro asserts that Whitman's prophetic, or "biblical" quality is a main cause for the Modernist dislike of Whitman, as well as Lawrence: "it is the biblical quality of Whitman (as with Lawrence) that is so offensive to lovers of Literature. What insolence! they say, and they are right. For neither Whitman nor Lawrence were 'writers'; they were prophets. Literature makes it its business to stone prophets" (161). Shapiro thus comes to think of Whitman as all-American and a prophet, two roles with a strong exilic dimension. Whitman is American, but not perceived by the majority as the father of American poetry. Whitman is also a prophet, but as prophet, his orientation is more dissident than participant.

Ascribing Jewish connotations of prophecy to Whitman is significant, especially when this characterization comes from Shapiro. By understanding Whitman as a prophetic poet, presumably like any of the numerous Jewish prophets of the Bible, one with extraordinary vision, knowledge, and insight, Shapiro positions Whitman within a Jewish context. These dual attributes of American and prophet are Shapiro's explanations for the Modernists' rejection of Whitman, a rejection that he (Shapiro) experienced as a Jew. As the next section will address, there is great gain for Shapiro in turning Whitman into a prophetic poet and thus a quasi-Jew.

\section{Shapiro's Whitman, Shapiro's few}

With Shapiro's understanding of Whitman as an American poet in exile, is it surprising that Shapiro's vision of Whitman resonates with his vision of the "Jew" and Jewishness itself? This correlation becomes evident when looking at descriptions of Jewish identity in Shapiro's introduction to Poems of a few. In this collection, every poem explores some aspect or aspects of Jewishness, including language, culture, the 
Holocaust, and Israel. Ironically, Shapiro claims not to be "concerned" with "The Jewish Question," "Judaism," "Jewry," or "Israel” (9). This contradiction is reflective of a certain inconsistency or vacillation throughout the introduction, whereby Shapiro particularizes Jewishness on the one hand and generalizes it on the other. Shapiro claims that the "undercurrent" of the poems in the collection is the Jew, and that the Jew is at the "center" of the collection. At the same time, he insists that the poems are intended to be "universal":

[These poems] are not for poets. They are for people who derive some strength of meaning from the writings of poets and who seek in the poet's mind some clue to their own thoughts. ... These poems are documents of an obsession. This obsession, I believe, is universal and timeless; the Jew is at its center, but everyone else partakes in it. (9)

Shapiro thus emphasizes the uniquely Jewish nature of the collection, but equates the Jew with "universality" and "timelessness." Richard Slotkin has commented on the association between Jewishness and human suffering that Shapiro brings up. For Shapiro, Slotkin claims, the Jew is "a modern man . . . a humanist intimate with God through his intimacy with the pain, suffering, humiliations and joys of the world." 25 The ethnocentricity implicit in Shapiro's statement, whereby the Jew is at the center of his "obsession" for others to "partake in," demonstrates some lack of self-reflexiveness regarding his identity. This aside, Shapiro attempts to bring Jews from the margin to the center by theorizing the Jewish condition as that of human suffering, of "everyman."

In a later passage, Shapiro writes that being Jewish is to possess an "inescapable state of consciousness," which again contradicts his notion that the Jew represents a broader, human experience:

No one has been able to define $\mathcal{F e w}$, and in essence this defiance of definition is the central meaning of Jewish consciousness. For to be a Jew is to be in a certain state of consciousness which is inescapable. As everyone knows, a Jew who becomes an atheist remains a Jew. A Jew who becomes a Catholic remains a Jew. Being a Jew is the consciousness of being a Jew, and the Jewish identity, with or without religion, with or without history, is the significant fact. (10)

By claiming that the Jew is "inescapable" from himself, that is to say permanently (essentially) a Jew, Shapiro infers that Jewishness is a particular state of being. However, Shapiro reverts to his previous position, stressing the idea of Jews as a "divine," transcendent people:

The Jew is absolutely committed to the world. This people beyond philosophy, beyond art, virtually beyond religion, a stranger even to mysticism, finds itself at the very center of the divine manifestation-man. The Jew represents the primitive ego of the human race ... the Jew cannot be erased from human consciousness, even by force. (10) 
Shapiro accentuates the uniqueness of the Jew, while at the same time conceptualizing the Jew as representative of the "human race" or, as Flanzbaum states, "thrust[ing] the Jew into the world of metaphor" (269). He goes so far as to suggest that the Jews who suffered in the Holocaust represent the suffering of all mankind:

The hideous blood purge of the Jews by Germany in the twentieth century revived throughout the world the spiritual image of the Jew not as someone noble and good, or despicable and evil . . . but as man essentially himself, beyond nationality, defenseless against the crushing impersonality of history. (Poems of a few 10)

Crucially, the very particularity of the victimization of Jews in the Holocaust is the root cause of the universalizing potential that Jews possess. Karl Malkoff has summarized Shapiro's view, that the Jew becomes "a terrible symbol of the Holocaust, of man brought face to face with annihilation." ${ }^{26}$ For Shapiro, the "evil" faced by Jews is that faced by all humanity. ${ }^{27}$

When Shapiro's rhetoric about the Jew is compared to his rhetoric about Whitman, the similarities are striking. As discussed earlier, Shapiro considered Whitman to be transcendent, "beyond" any aesthetic, culture, or nation. Whitman, Shapiro stated, "looked beyond literature and beyond the greatness of art. His true personality went out beyond America, beyond religions and even beyond mankind. ... Whitman accepted death ... he triumphed over it. He saw beyond history and beyond America" ("White Aboriginal" 171-172). Later, Shapiro again employed the term "beyond" to describe Whitman: "Because Whitman is beyond the law of literature he is condemned to extinction from generation to generation... . Whitman is beyond the reach of criticism, beyond Congress and the Church, and yet there, right under your nose" (174). As shown earlier, in Poems of a few, Shapiro bestows this precise marker of "beyond" upon Jews: "beyond philosophy," "beyond art," "virtually beyond religion." In the case of the Jew and Whitman, the quality of "beyond" implies that the Jew and Whitman are outsiders, yet also insiders, belonging to the very context which they supposedly transcend. Whitman is therefore inherently American (and implicitly Jewish), while Jews are inherently Jewish (and implicitly American).

This scheme of comparison between Shapiro's Whitman and Shapiro's Jew can crucially be understood in terms of Shapiro's own religious, cultural, and creative identity. His modes of perceiving these two figures echo his experience of cultural alienation. As a poet in America, Shapiro is Shapiro's Whitman himself: an American, but an outsider, resistant to the role of American spokesman. As a Jew, Shapiro's identity is likewise malleable, claiming his Jewishness in Poems of a few, but swerving from it with an insistence on transferring Jewishness to 
the status of symbol. Shapiro and Whitman therefore both occupy the role of outsider with regards to mainstream American poetry. Shapiro himself is Jewish and American, although, in the spirit of Whitman, "beyond" these categories as well.

Shapiro's notions about Whitman appear not just in prose, but in poetry. Shapiro does not profess Whitman to be a major stylistic influence, often displaying un-Whitmanian structured stanza forms, short lines, and sparse language. However, Whitman's signature catalogues and repetitions clearly recur in several of Shapiro's collections, such as Person, Place and Thing (1942), V-Letter and Other Poems (1945), Trial of a Poet (1947), Poems of a few, and The Bourgeois Poet (1964). A poem from The Bourgeois Poet, which I consider here, "I am an Atheist Who Says His Prayers," exemplifies how the conjoining of Whitman and Jewishness in Shapiro's prose becomes manifest poetically (CP 180-181). The speaker of the poem, explicitly Jewish and American, describes a fragmented self, one that refuses to conform to a single religious, cultural, or social identity. The opening lines of the poem call attention to Shapiro's various definitions of identity, suggesting, as Whitman famously does in "Song of Myself," that contradictions of the self might as well be embraced, since they cannot be effaced. With a distinctly Whitmanian "I," and his trademark sense of (Jewish?) humor, the speaker enumerates his selves:

I am an atheist who says his prayers.

I am an anarchist, and a full professor at that. I take the loyalty oath.

I am a deviate. I fondle and contribute, backscuttle and brown, father of three.

I stand high in the community. My name is in Who's Who. People argue about my modesty.

I drink my share and yours and never have enough. I free-load officially and unofficially.

A physical coward, I take on all intellectuals, established poets, popes, rabbis, chiefs of staff.

I am a mystic. I will take an oath that I have seen the Virgin. Under the dry pandanus, to the scratching of kangaroo rats, I achieve psychic onanism. My tree of nerves electrocutes itself.

$[\ldots .$.

Pitchpots flicker in the lemon groves. I gaze down on the plains of Hollywood. My fine tan and my arrogance, my gray hair and my sneakers, O Israel!

Wherever I am I become. The power of entry is with me. In the doctor's office a patient, calm and humiliated. In the foreign movies a native, shabby enough. In the art gallery a person of authority (there's a secret way of approaching a picture. Others move off). The high official insults me to my face. I say nothing and accept the job. He offers me whiskey. 
How beautifully I fake! I convince myself with men's room jokes and epigrams. I paint myself into a corner and escape on pulleys of the unknown. Whatever I think at the moment is true. Turn me around in my tracks; I will take your side.

For the rest, I improvise and am not spiteful and water the plants on the cocktail table.

Judaism is referenced explicitly only once in the poem, when Shapiro writes (immediately after the break above), "O Israel," a recognizable Jewish credo. It is mainly the recitation of the speaker's changing self that marks him as a Jew, as long as we understand the Jew, as Shapiro does, to represent everyman in the symbolic sense. Throughout the poem, Shapiro takes on a myriad of identities, being thus "beyond" any specific one. The first line, "I am an atheist who says his prayers," bespeaks the contradiction of a secular Jewish poet who resists, yet is attached to, religious tradition. In line two, Shapiro presents another contradiction, that of being against institutions as an "anarchist," but part of one as a "professor" (which biographically he was). By line three, the speaker expresses, even celebrates, his non-conformity: "I am a deviate." The speaker's plurality of selves is carried through the poem with the Whitmanian anaphora of "I": "A physical coward, I take on all intellectuals, established poets, popes, rabbis, / chiefs of staff." The speaker's changing of identities takes place not just between stanzas, but at times within the same line. With this Whitmanian "I," the speaker also claims to be a "mystic": "I am a mystic. I will take an oath that I have seen the Virgin. Under the / dry pandanus, to the scratching of kangaroo rats, I achieve psychic / onanism. My tree of nerves electrocutes itself." As stated earlier, Shapiro frequently marks Whitman as a mystic. As mystic himself, Shapiro may reach a higher spiritual and psychical plane, but as an American, he must inevitably "[uphold] the image of America."

The fluidly shifting "I" and Shapiro's cataloguing of identities clearly evoke the contradictory Whitmanian persona in "Song of Myself": "I am of old and young, of the foolish as much as the wise, / Regardless of others, ever regardful of others, / Maternal as well as paternal, a child as well as a man . . . . . . I resist anything better than my own diversity" (PP 42-43). The contradictions that comprise Whitman's "diversity" are those that make him potentially relatable by readers of various backgrounds, which may serve to contribute to Whitman's appeal. Shapiro's speaker as well possesses a plethora of identities, which is to say many, but none fully or permanently. Shapiro seems to regard this transient or impermanent condition with humor throughout the poem, though this humor can be read as a thin veil that fails to mask the speaker's underlying distress: "How beautifully I fake! . . . / Whatever I think at the moment is true. Turn me around / in my tracks; I 
will take your side." The connection that Shapiro insists on between immutability and Jewishness must not be neglected. The speaker of "Atheist" is both an American insider and a Jewish outsider, himself a Jewish Whitman.

\section{Conclusion}

The writings of Karl Shapiro reveal an enlistment of Whitman to counteract the discriminatory attitudes Shapiro faced as a Jew and poet in American society. We have seen how in Shapiro's work Whitman effectively becomes a Jew, or at least takes on the position of the Jew in Shapiro's vision of what it means to be both a Jew and outsider in America. Shapiro's appropriation of Whitman gives us an example of how Whitman's influence on Jewish-American poets extends beyond, and is quite different, from the case of Ginsberg. Clearly, Shapiro's turn to Whitman differs markedly from Ginsberg's in both theme and form. One would hardly find in Shapiro the references to the body and sexuality that Ginsberg adopted from Whitman. Nor does Shapiro's poetic style reflect Whitman's as directly as Ginsberg's long lines and cataloguing. It is perhaps unsurprising that in an interview with Philips, Shapiro claims not to greatly approve of Ginsberg's use of Whitman:

I am not crazy about the Whitman element in Ginsberg; it seems to me Ginsberg knew what Whitman was doing, but Ginsberg is a programmer and a propagandist and a politician. His poetry has suffered very badly. There's some great stuff - poetry of lamentation and so on - but so much of it is theatrical and phony. (56)

And yet, poetic manifestations and declarations aside, both Shapiro and Ginsberg adopted Whitman to similar ends: to confront various forces of political and social intolerance, whether in the realm of race, religion, or sexuality. The two poets brought Whitman to the fore as part of their own visions of a more liberal, inclusive American society, one that included them as well.

The poets hone in on Whitman's pluralistic and egalitarian vision, one that accepts and embraces the minority. In the story of the Jewish-American appropriation of Whitman, these aspects helped them negotiate their hyphenated identity. Thus Jewish American poets like Shapiro and Ginsberg, as well as others not discussed here, partake in the shaping of Whitman's reputation in America, in conjunction with the shaping of an ever-shifting Jewish identity. The Jewish appropriation of Whitman underscores the deeply American notion of the possibility of transformation: Whitman into a Jew, Shapiro into an American.

Tel Aviv University 


\section{NOTES}

I would like to thank my dissertation advisers, Karen Alkalay-Gut and Hana WirthNesher, without whom this research would not have come to fruition.

1 Studies from the 1960s on Allen Ginsberg and Walt Whitman include M. L. Rosenthal, The New Poets: American and British Poetry Since World War II (New York: Oxford University Press, 1967) and Allen Grossman, "The Jew as an American Poet: The Instance of Ginsberg," in The Long Schoolroom: Lessons in the Bitter Logic of the Poetic Principle (Ann Arbor: University of Michigan Press, 1997), 150-167. More recently, Alicia Ostriker has explored the link between Whitman and Ginsberg's Jewish writing in "'Howl' Revisited: The Poet as Jew," Dancing at the Devil's Party: Essays on Poetry, Politics, and the Erotic (Ann Arbor: University of Michigan Press, 2000), 101-120. Ostriker's reading of Ginsberg's reading of Whitman (in this essay, as well as another essay in the collection, "Loving Walt Whitman and the Problem of America") marks not only how Ginsberg interprets Whitman, but also how Ginsberg's reading of Whitman has come to influence Ostriker herself.

2 My dissertation, "Walt Whitman and Jewish American Poetry" (Tel Aviv University, 2011), attempted to remedy this lack of research by investigating Whitman's influence on Charles Reznikoff, Muriel Rukeyser, Alicia Ostriker, Marge Piercy, Gerald Stern, and C. K. Williams, in addition to Shapiro. A partial list of poets whose adoptions of Whitman still wait to be examined would include Delmore Schwartz, Louis Zukofsky, Carl Rakosi, George Oppen, Aaron Kramer, Kenneth Koch, Harvey Shapiro, Adrienne Rich, Irving Feldman, Jorie Graham, Philip Levine, Robert Pinsky, Charles Bernstein, and Jerome Rothenberg.

3 Karl Shapiro, Poems of a few (New York: Random House, 1958); hereafter, Poems of a few.

4 A poem by Louis D. Rubin, dedicated to Shapiro and titled "The Poet in Eclipse," marks the decrease in attention to Shapiro's work: "Prestigious editors no longer chatter / About him at cocktail parties. / Critics do not debate his latest heresies. / The turncoat anthologists have dropped him / From the canon of those who matter." The Sewanee Review 99 (1991), 554-556. However, notable studies on Shapiro have been undertaken, such as: Steven Gould Axelrod, "The Middle Generation and WWII: Jarrell, Shapiro, Brooks, Bishop, Lowell," War, Literature, and the Arts: An International Fournal of the Humanities 11 (1999), 1-41; Hilene Flanzbaum, ed., "The Imaginary Jew and the American Poet," The Americanization of the Holocaust (Baltimore: Johns Hopkins University Press, 1999), hereafter, “The Imaginary Jew"; Sue B. Walker, ed., Seriously Meeting Karl Shapiro (Mobile, Alabama: Negative Capability Press, 1993).

5 Pound and other Modernist poets largely disliked Whitman; however, Betsy Erkkila demonstrates that Whitman did in fact influence their poetry, both directly and through French writers like Baudelaire; see Walt Whitman Among the French (Princeton University Press, 1980).

6 Cited in: Robert S. Phillips, "Karl Shapiro," in The Madness of Art: Interviews with Poets and Writers (Syracuse University Press, 2003), 58; hereafter, The Madness of Art.

7 Of the leading Modernist figures, Shapiro approved only of Williams, stating that Williams had protested the "sell-out poetry" of High Modernism by dismissing it as "... [a] kind of effeminate formalism"; "The Three Hockey Games of T. S. Eliot," The Antioch Review 22.3 (1962), 285; hereafter, "The Three Hockey Games." Shapiro's admiration of Williams can also be seen in context with Williams' more favorable 
attitude toward Whitman. For a discussion of Williams' indebtedness to Whitman, refer to Stephen Tapscott, American Beauty: William Carlos Williams and the Modernist Whitman (New York: Columbia University Press, 1984).

8 I would like to thank Matt Miller (Yeshiva University), whose insights were vastly helpful in articulating my claims.

9 Louis D. Rubin, for instance, claimed, “[Shapiro's] strength as a poet had come from his ability to invest the objects and emotions of middle-class American experience with the language and dignity of poetry. His first mature collection . . . had taken for subject matter such things as new cars, drugstores, barbershops, row houses, railway stations ... [and] transformed them into poems that imaged them with a clarity and even a literary radiance that they had not hitherto received." "Karl Shapiro 19132000: He Took His Stands," The Sewanee Review 109.1 (2001), 109; hereafter, "Karl Shapiro 1913-2000.”

10 See Hayden Carruth, "A Salute in Time," in Seriously Meeting Karl Shapiro, ed. Sue B. Walker (Mobile, Alabama: Negative Capabilities Press, 1993), 4.

11 Images of American youth culture and iconic symbols of sports, jazz, and CocaCola exemplify Shapiro's project of representing the working-class American experience. These "facts, neuroses ... and vulgarities of America" are evident throughout Shapiro's poems, such as "Drug Store": "Youth comes to jingle nickels and crack wise; / The baseball scores are his, the magazines / devoted to lust, the jazz, the Coca-Cola, / The lending library of love's latest. / He is the customer; he is heroized...." Collected Poems (New York: Random House, 1978), 11; hereafter, CP.

12 Shapiro served as chief editor from 1950-1955. For a discussion of Shapiro's tenure at Poetry, see Diederik Oostdijk, "Someplace Called Poetry: Karl Shapiro, Poetry Magazine and Post-War American Poetry," English Studies 4 (2000), 346-357.

13 Cited in David R. Slavitt, "Karl (Jay) Shapiro," Contemporary fewish-American Dramatists and Poets, ed. Joel Shatsky and Michael Taub (Westport, CT: Greenwood Press, 1999), 554.

14 Alan Wald, Exiles from a Future Time: The Forging of the Mid-Twentieth Century Literary Left (Chapel Hill: University of North Carolina Press, 2002).

15 John Hollander, "The Question of American Jewish Poetry," in What Is fewish Literature?, ed. Hana Wirth-Nesher (New York: Jewish Publication Society, 1994), $40,43$.

16 "University" is yet another poem that speaks to issues of not only religious, but racial and ethnic discrimination: "To hurt the Negro and avoid the Jew / Is the curriculum" (CP 10). Shapiro condemns institutions that exclude minorities ("Negros" and "Jews"), which is especially significant because of his own Jewish identity.

17 Walt Whitman, Poetry and Prose, ed. Justin Kaplan (New York: Library of America, 1996), 7; hereafter, $P P$.

18 Shapiro, "The First White Aboriginal," in Start with the Sun: Studies in the Whitman Tradition, ed. James E. Miller, Jr., Karl Shapiro, and Bernice Slote (Lincoln: University of Nebraska Press, 1960), 60; herafter, "White Aboriginal."

19 Shapiro, "Is Poetry an American Art?," College English 25.6 (1964), 399; hereafter, "Is Poetry an American Art?" 
20 Robert W. Daniel, "Paleface and Redskin," The Sewanee Review 84.3 (1976), xc.

21 Shapiro, The Poetry Wreck (New York: Random House, 1975), xv.

22 Shapiro, Essay on Rime (New York: Random House, 1945), 16.

23 Shapiro, "Cosmic Consciousness," in Start With the Sun, 30-31; hereafter, "Cosmic Consciousness."

24 Shapiro defines cosmic consciousness as "[a] sense of identification with the universe, and intellectual enlightenment or illumination which may last only briefly ... but which places the individual on a new plane of existence" ("Cosmic Consciousness" 31).

25 Richard Slotkin, "The Contextual Symbol: Karl Shapiro's Image of 'The Jew,"” American Quarterly 18.2 (1966), 220.

26 Karl Malkoff, "The Self in the Modern World: Karl Shapiro's Jewish Poems," Contemporary American-fewish Literature, ed. Irving Malin (Bloomington: Indiana University Press, 1973), 214.

27 Years after Poems of a few was published, Shapiro qualified claims in his introduction, particularly his universalizing of Jewish suffering. In "The-American-JewishWriter," he states, "What my collection of poems tried to illustrate was my belief that the Jew is absolutely committed to the world, and it is the commitment which also makes him, when he is here, so intensely American." MELUS 3.2 (1976), 6-9. However, in this belated qualification, Shapiro merely imposes a new responsibility upon the Jew: to represent the American. In this way, Shapiro's Jew in his exile and suffering is at once inescapably Jewish, yet a representative of America, as well as humanity at large. 